\title{
Erratum to: Search for informative polymorphisms in candidate genes: clock genes and circadian behaviour in blue tits
}

\author{
C. Steinmeyer · J. C. Mueller · B. Kempenaers
}

Published online: 5 March 2010

(C) Springer Science+Business Media B.V. 2010

Erratum to: Genetica (2009) 136:109-117

DOI 10.1007/s10709-008-9318-y

This article was intended for publication in the Special Issue of Ecological Genomics.
An error of classification during peer review process has prevented its inclusion in this special issue, as it has been published earlier in Volume 136, Number 1.

The online version of the original article can be found under doi: 10.1007/s10709-008-9318-y. 